Fak. Ilmu Tarbiyah dan Keguruan

UIN Sumatera Utara Medan

\title{
PERANGKAT KERAS KOMPUTER
}

\author{
ANNISA NUR SAFITRA HASIBUAN (0305193127) \\ Pendidikan Matematika-3
}

Fakultas Ilmu Tarbiyah dan Keguruan

Email : annisanursafitrahasibuan@gmail.com

\begin{abstract}
Perangkat keras merupakan perangkat yang dapat dilihat dirasah secara langsung oleh manusia. Perangkat keras komputer adalah semua bagian fisik komputer, dibedakan dengan data yang berada didalamnya atau yang beroperasi di dalamnya sedangkan perangkat lunak merupakan perangkat yang dapat dilihat dan tidak dapat disentuh secara langsung oleh manusia, perangkat lunak yang menyediakan instruksi buat perangkat keras untuk menyelesaikan tugasnya.
\end{abstract}

Kata kunci : Perangkat Keras

\section{PENDAHULUAN}

Semakin majunya perkembangan zaman dan persaingan globalisasi yang terjadi mengharuskan setiap individu memiliki kreativitas dan semangat yang tinggi untuk menjalankan roda kehidupannya yakni dengan penggunaan teknologi informasi seperti multimedia. Alat bantu teknologi yang berkaitan dengan komputer sangat dibutuhkan dalam proses pembelajaran yang lebih baik dan mudah. Misalnya saja alat pembelajaran untuk sub-sub bidang hardware komputer. Sebagian pengguna komputer saat ini, baik itu dari kalangan siswa dan mahasiswa hanya mampu untuk mengoperasikan software komputer, tanpa mengetahui apa saja komponen dari.

hardware komputer, sedangkan suatu sistem komputer didukung oleh tiga komponen utama yaitu, Software, Hardware, dan Brainware. Ketiga komponen ini tidak akan berjalan dengan baik apabila salah satunya mengalami masalah. Aplikasi interaktif ini akan menjelaskan tentanhardware dari komputer, baik itu prinsip kerja, fungsi, dan karakteristik dari masing- masing komponen. Pada kesempatan ini, penulis ingin membuat aplikasi untuk memvisualisasikan materi pelajaran yang akan membantu sebagai media pembelajaran dan bermain. Dimana tampilan dan interface aplikasi.

lebih menyenangkan serta tidak membosankan karena lebih banyak animasi yang terkandung dalam aplikasi ini. Berdasarkan latar belakang masalah di atas, 
maka dapat dirumuskan permasalahannya yaitu bagaimana membangun aplikasi interaktif spesifikasi hardware komputer dengan menggunakan Macromedia Flash 8. Batasan permasalahan yang dibahas pada penelitian ini hanya tentang pengenalan.

hardware komputer dan tidak membahas tentang komputer secara keseluruhan. Adapun metodologi penelitian yang dilakukan dalam penelitian ini adalah Penelitian Pustaka (Library Research), Metode Pengamatan (Observation).

Istilah komputer (computer) di ambil dari bahasa latin computer yang berarti menghitung (to comaipute/to reckon).

Dimana teknologi komputer merupakan pendukung bahkan penggerak kemajuan teknologi informasi pada jaman sekarang ini. Dan tidak bisa dipungkiri bahwa ilmu elektronika sangat berpengaruh kepada perkembangan Teknologi. Sebuah komputer mampu mengendalikan sebuah rangkaian alat elektronika menggunakan sebuah chip IC yang dapat diisi program dan logika yang disebut teknologi MikroProcessor. Didalam komputer tidak bisa dipisahkan dari yang namanya Processor.

Dimana teknologi komputer merupakan pendukung seluruh kegiatan aspek manusia bahkan penggerak kemajuan teknologi informasi pada jaman sekarang ini. Dan tidak bisa dipungkiri bahwa ilmu elektronika sangat berpengaruh kepada perkembangan Teknologi komputer. Di dalam sebuah komputer tersebut terdapat sebuah komponen yang berfungsi untuk menghasilkan visual dari computer dan hardware yang memberikan perintah kepada computer untuk menampilkan keluaran visual yang disebut dengan VGA .

\section{BAB 2 PEMBAHASAN}

\subsection{Metode}

Di dalam pembuatan makalah ini kami menggunakan metode yaitu Metode Pustaka. Kami mencari beberapa sumber yang terkait dengan makalah ini seperti dibuku, majalah maupun internet untuk mendapatkan banyak informasi mengenai Processor, Motherboard dan VGA.

\subsection{Processor INTEL dan AMD}

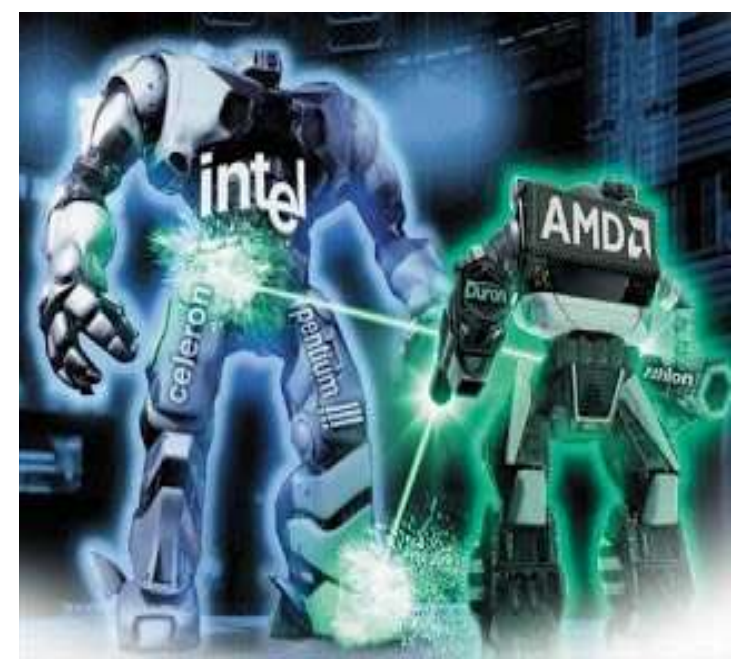

Processor adalah sebuah chip yang berupa Integrated Circuit (IC) yang mengontrol keseluruhan sistem komputer dan digunakan sebagai pusat atau otak dari kegiatan komputer dalam melakukan perhitungan dan menjalankan tugas input 
dan output. Processor terletak pada soket yang ada di motherboard. Processor dapat diganti dengan jenis yang lain asalkan socket pada motherboard sesuai dan sistem pada motherboard mendukung arsitektur processor tersebut.

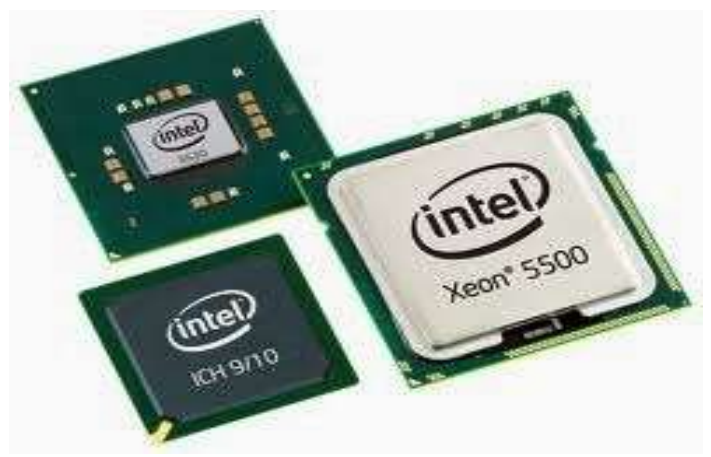

Kecepatan processor mempengaruhi kecepatan komputer secara signifikan karena benda satu ini adalah merupakan pusat pengolahan data. Processor saat ini sering disebut microprocessor karena ukurannya yang sangat kecil secara fisik namun memiliki kecepatan proses yang besar.

Processor terbagi menjadi tiga bagian penting, yakni :

\section{Aritcmatics Logical Unit (ALU)}

Aritcmatics Logical Unit (ALU) merupakan pusat untuk menghitung operasi aritmatika dan logika untuk menjalankan semua perintah yang harus dilaksanakan oleh sebuah komputer.

\section{Control Unit (CU)}

Control Unit (CU) merupakan bagian yang menjadi pengatur semua lalulintas data dan perhitungan yang dilakukan oleh processor. dengan adanya kontrol unit ini, semua perhitungan dan eksekusi yang harus di jalankan dapat dilakukan secara berurutan tanpa adanya tumpang tindih antara satu perintah denga perintah lainnya.

\section{Memori Unit (MU)}

Memori Unit (MU) memori unit merupakan unit pendukung, dimana semua perintah yang sering digunakan oleh processor akan disimpan sementara di bagian ini. dengan adanya memori unit, processor tidak lagi memanggil perintah yang sama kebagian lain.dengan demikian, waktu yang digunakan untuk menjalankan perintah perintah dapat dipersingkat. pada processor modern memori unit sudah ada pada bagian processornya ( CORE ) dan dikenal dengan nama cache memori. Hal inilah yang mempengaruhi kinerja kecepatan sebuah Eksekusi.

Masing-masing

bagian processor ini memiliki tugas masing-masing sesuai dengan namanya. Processor saat 
ini memiliki banyak merek, namun yang terkenal di Indonesia hanya ada dua, yakni INTEL dan AMD. Padahal masih banyak merek lain, yakni Cyrix dari VIA, IBM PowerPC, IDT dan Apple.

\section{INTEL Corporation}

INTEL Corporation adalah sebuah perusahaan multinasional yang berpusat di AS dan terkenal dengan rancangan dan produksi mikroprocessor dan mengkhususkan dalam sirkuit terpadu. INTEL juga membuat kartu jaringan, chipset papan induk, komponen, dan alat lainnya. INTEL memiliki projek riset yang maju dalam seluruh aspek produksi semikonduktor, termasuk MEMS. INTEL mengganti logo dan sloganya pada 1 Januari 2008. Slogan lamanya "INTEL inside" diganti dengan "INTEL Leap Ahead"

Beberapa produk processor INTEL yang ada sampai sekarang ini yaitu :

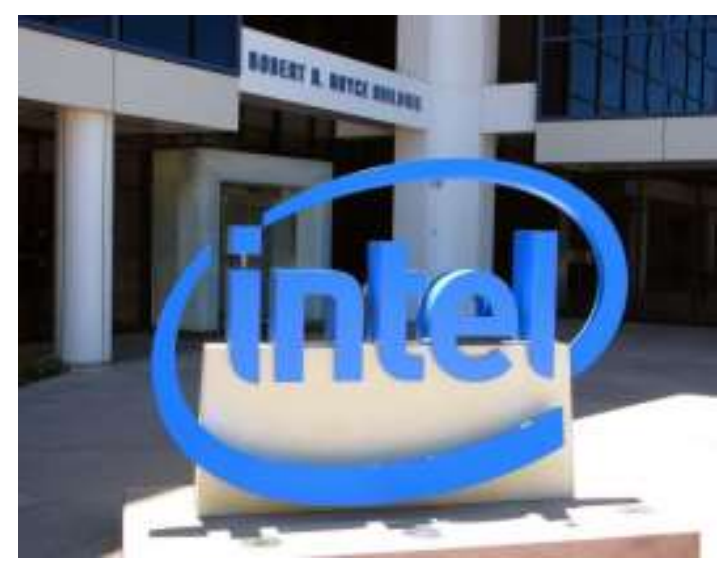

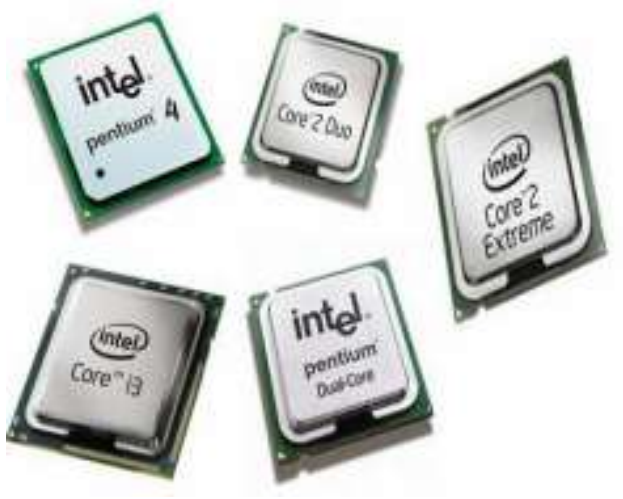

1. INTEL $®$ Pentium $® 4$

2. INTEL® Pentium $®$ Dual-Core

3. INTEL ${ }^{\circledR}$ Core $^{\mathrm{TM}} 2$ Duo

4. INTEL $®$ Core $^{\mathrm{TM}} 2$ Quad

5. INTEL ${ }^{\circledR}$ Core $^{\mathrm{TM}} 2$ Extrme

6. INTEL $®$ Core $^{\mathrm{TM}} \mathrm{i} 3, \mathrm{i} 5, \mathrm{i} 7$

\section{AMD Corporation}

AMD (Advanced Micro Devices) adalah sebuah perusahaan pembuat sirkuit terpadu, processor atau IC (integrated circuit) yang bermarkas di Sunnyvale, California, Amerika. Pabrik pertama berada di Austin, Texas, Amerika dan pabrik kedua berada di Dresden, Jerman yang ditetapkan untuk memproduksi Athlon saja. Bila semuanya berjalan lancar, mimpi harga sistim PC akan dapat lebih murah bisa terwujud karena tidak lagi di monopoli oleh INTEL. Pada tahun 2006 juga, AMD telah berhasil mengakuisisi perusahaan Grafis terkenal asal Amerika yaitu ATI Tecnology. 


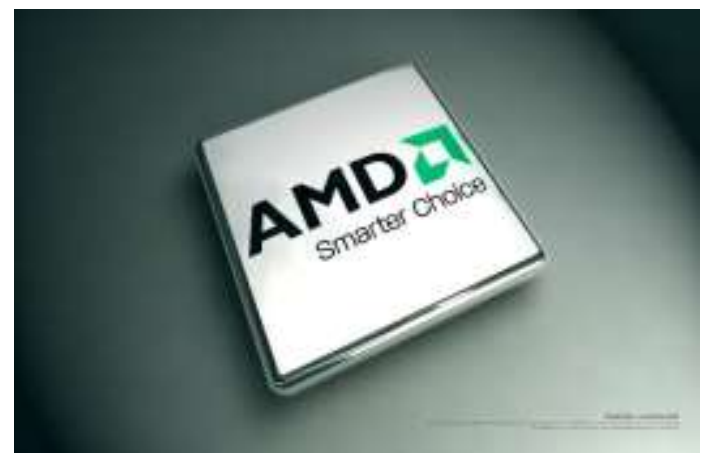

Perusahaan ini adalah penyedia processor x86-compatible processors terbesar kedua. AMD juga sudah dikenal oleh dunia, beberapa produknya yaitu

1. AMD Sempron ${ }^{\mathrm{TM}}$

2. AMD Athlon ${ }^{\mathrm{TM}} \mathrm{FX}$

3. AMD Athlon ${ }^{\mathrm{TM}} 64$

4. AMD Athlon ${ }^{\mathrm{TM}} \mathrm{X} 2$

5. AMD PHENOM ${ }^{\mathrm{TM}} \mathrm{X} 3$

6. AMD PHENOM ${ }^{\mathrm{TM}} \mathrm{X} 4$

7. AMD bulldozer

AMD Bulldozer merupakan processor yang diklaim tercepat saat ini. Dan itu merupakan saingan dari Core i7 milik INTEL. Tentu kita punya pilihan yang sama-sama mumpuni untuk processor, entah itu INTEL maupaun AMD. Keduanya sama sama baik (Wiyono, 2014).

\subsection{Kelebihan dan Kekurangan Processor INTEL dan Processor AMD}

Setiap barang pasti ada kelebihan dan kekurangan, sama halnya dengan
Processor pada komputer. Berikut beberapa perbedaan processor INTEL dan AMD :

\section{AMD}
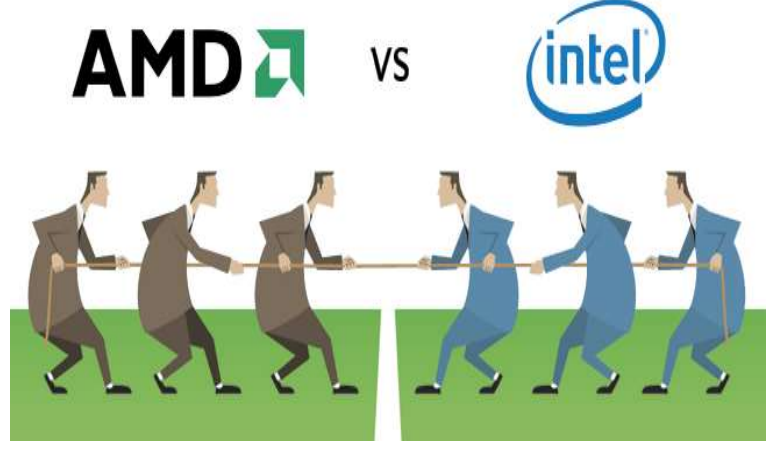

Set instruksi pada INTEL adalah MMX, SSE,SSE2, dan SSE3, tetapi pada AMD SSE2 dan 3DNow. Tetapi dari sekian banyak istruksi yang dipakai oleh INTEL sebetulnya telah ada dalam 3DNow-nya AMD yang tidak dimiliki oleh INTEL.

1. L1 pada INTEL maksimal 32K, sedang pada AMD adalah 128K. Bedasarkan beberapa test AMD dengan L1 128K lebih unggul dibanding dengan INTEL.

2. Banyak transistor pada INTEL 100 milyar sedang AMD 105 milyar.

3. Banyaknya Decoder, Integer, FP pada INTEL lebih sedikit dibanding AMD yang secara signifikan perbedaan tersebut meningkatan kinerja dari AMD.

4. Temperatur pada INTEL dapat diatur oleh processornya sendiri (processor akan mengurangi kecepatan jika processor terlalu 
panas), pada AMD64 temperatur maksimum adalah 900C. Teknologi INTEL lebih unggul dibanding AMD.

5. AMD lebih unggul dalam pengolahan komunikasi aplikasi, seperti transfer data pada modem, ADSL, MP3, dan Doubly Digital Suround Sound.

6. Pipeline pada INTEL lebih panjang dibanding dengan AMD, tetapi pipeline INTEL bermasalah pada pertukaran tugas, sehingga pipeline INTEL kecepatannya melambat berada dibawah AMD.

7. INTEL menang di brand image dan marketnya, sedangkan AMD harganya yang lebih murah.

8. Pada processor INTEL Pentium 4 harga standard, kinerjanya lumanyan cepat. Memang sih, untuk urusan grafis masshi kalah dibanding dengan AMD, tapi paling tidak processor INTEL tidak cepat panas.

9. Pada processor AMD Athlon harga agak murah dibanding INTEL. Grafis bagus banget, kecepatannya lumayan, tapi cepet banget panas dibandingkan INTEL (Wiyono, 2014).

Selain perbedaan diatas, kelebihan dan kekurangan Processor INTEL dengan Processor AMD adalah sebagai berikut.
Kelebihan Processor INTEL

- Temperatur pada INTEL dapat diatur oleh Processornya sendiri. Artinya Processor INTEL akan mengurangi kecepatan kinerjanya jika Processor terlalu panas

- Tidak berisik. Karena beberapa versi dari procesor INTEL tidak menggunakan pendingin aktif seperti kipas, melainkan hanya menggunakan heatsink saja

- INTEL menang di brand image dan pemasaran-nya. Mungkin ini dikarenakan INTEL ada lebih dulu ketimbang AMD

- Dengan harga yang standar (misalnya INTEL Pentium 4), kinerjanya sudah lumayan cepat

- Processor INTEL lebih kuat pada aplikasi multimedia

Kekurangan Processor INTEL

- Jika terjadi kerusakan akan membutuhkan biaya yang cukup mahal, karena pada beberapa produk, Processor dan motherboardnya menyatu.

- Lemah dalam urusan grafis

- Harus mengeluarkan biaya yang cukup mahal untuk performanya yang hebat 
Kelebihan Processor AMD

- Harga relatif lebih murah daripada procesor INTEL

- Hyper Transport Technology. Teknologi penggandaan bus pada jalur system sehingga data yang dapat diantar dalam satu waktu lebih banyak karena lalu lintas data yang lebih cepat

- Integrated Memory Controller. Memungkinkan Processor untuk melakukan pengaksesan memory langsung tanpa melewati chipset northbridge terlebih dahulu

- Enhanced Virus Protection. Teknologi yang memungkinkan Processor mendeteksi virus sehingga tidak akan diproses apabila terdeteksi

- Cool n' Quiet. Dengan teknologi ini memungkinkan penggunaan power yang efektif dan sistem yang lebih hening saat menggunakan kinerja sesuai dengan kebutuhan

- AMD64 Technology. Teknologi yang sangat mumpuni untuk menjalankan aplikasi-aplikasi yang berbasis 64 bit
Kekurangan Processor AMD

- AMD cepat panas. Namun itu dapat diatasi dengan cooler, seperti teknologi Ice Cool pada ASUS.

- AMD kurang terkenal jika dibandingkan dengan INTEL. Masyarakat lebih menggandrumi INTEL dibanding AMD

- Tidak semua game kompatibel dengan AMD (Khoiroh, 2013).

2.4 perbandingan antara Procesor INTEL Core I7-4790K dengan Processor AMD Visher FX-9590.
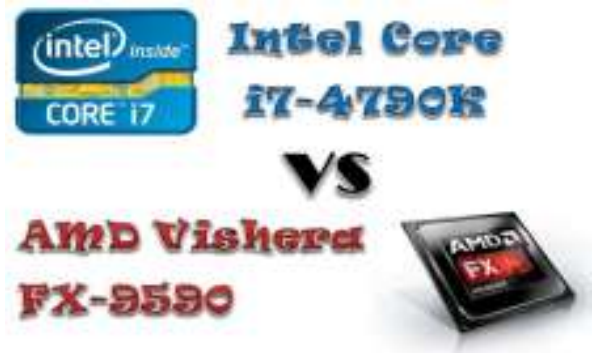

Seiring dengan perkembangan jaman, perusahaan Processor INTEL dan AMD bersaing untuk menciptakan Processor yang terbaik. Salah satunya untuk Processor INTEL yaitu INTEL Core i7-4790K dan Processor AMD yaitu AMD Vishera FX-9590 seperti gambar 2.7.

Untuk perbandingannya bisa dilihat di tabel 2.1. 


\section{Pengertian Motherboard}

Motherboard adalah perangkat

keras komputer yang berfungsi

untuk menancapkan dan

menghubungkan semua perangkat

keras komputer, dengan kata lain

motherboard sebagai sirkuit utama

dimana semua komponen

pendukung komputer akan

dihubungkan. Pada motherboard

terdapat komponen-komponen yang

sangat penting dan mempunyai

fungsi dan peranan masing-masing.

\subsection{Komponen pada Motherboard dan}

\section{fungsinya}

\section{Slot Prosessor}

Slot yang berfungsi untuk menancapkan atau meletakan prosessor pada komputer, Slot ini berbentuk persegi dengan ukuran sesuai dengan prosessor.

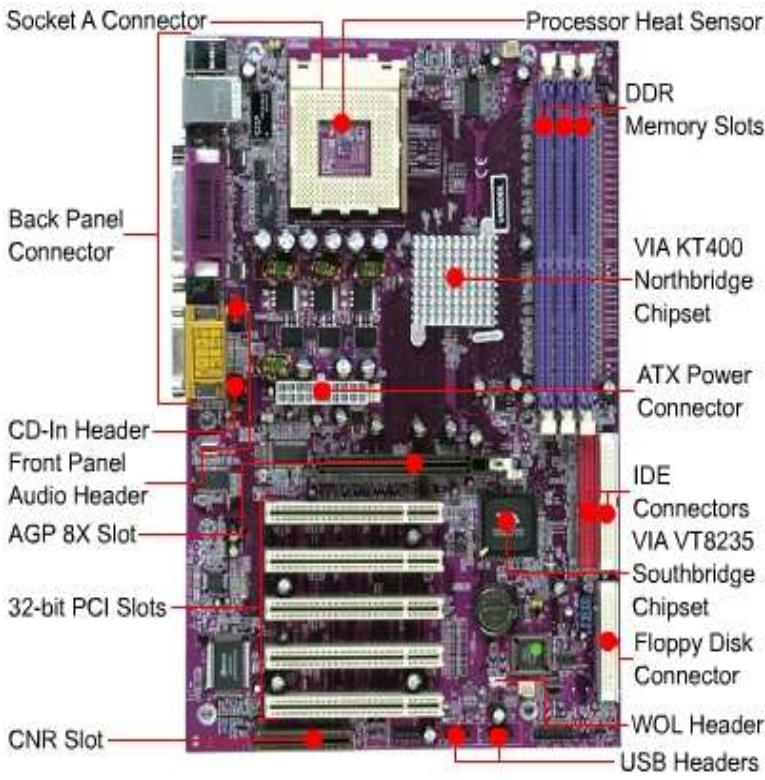

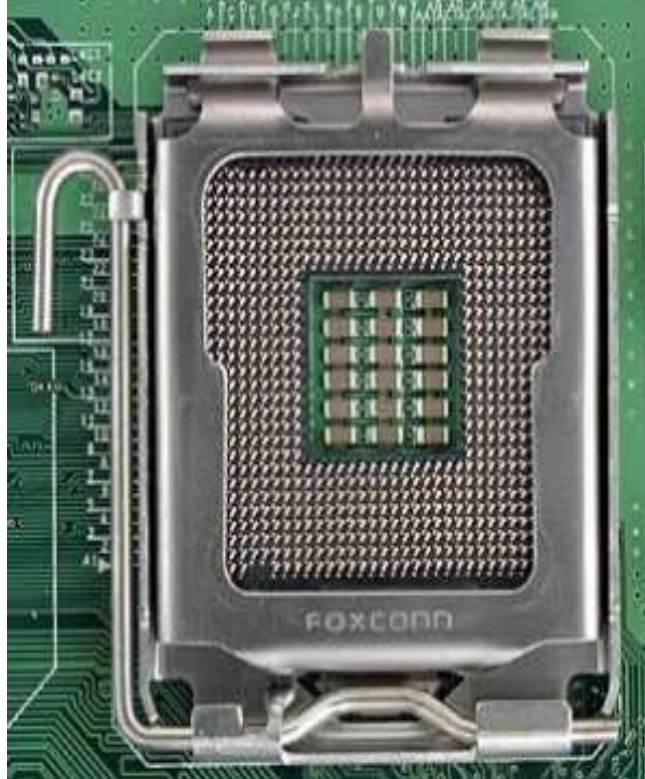

\section{Slot memori (RAM)}

Yaitu slot yang berfungsi untuk memasang RAM atau memori ke motherboard, Slot ini berbentuk panjang dengan pengunci di kanan dan kirinya yang berfungsi untuk mengunci memori atau ram yang sudah terpasang pada motherboard.

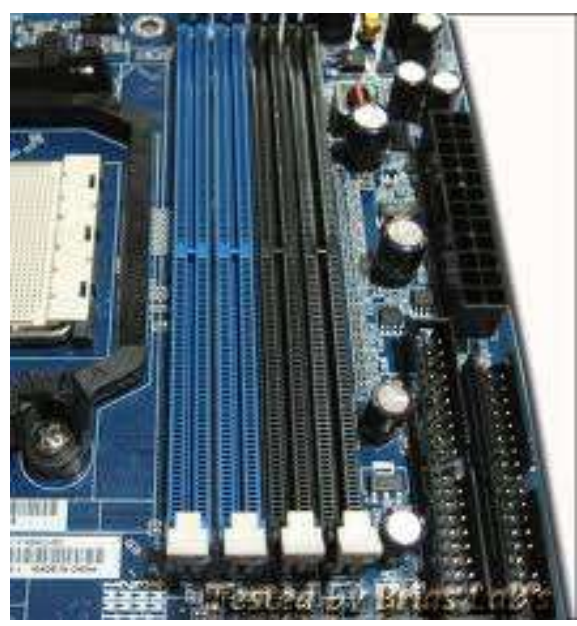

\section{3. chipset nortbridge}

Komponen yang berbentuk persegi yang menempel pada mottherboard yang berfungsi untuk mengatur lalu lintas data antara prosessor dengan sistem memori dan saluran uatama motherboard. Chipset ini 
biasanya terletak berada didekat prosessor.

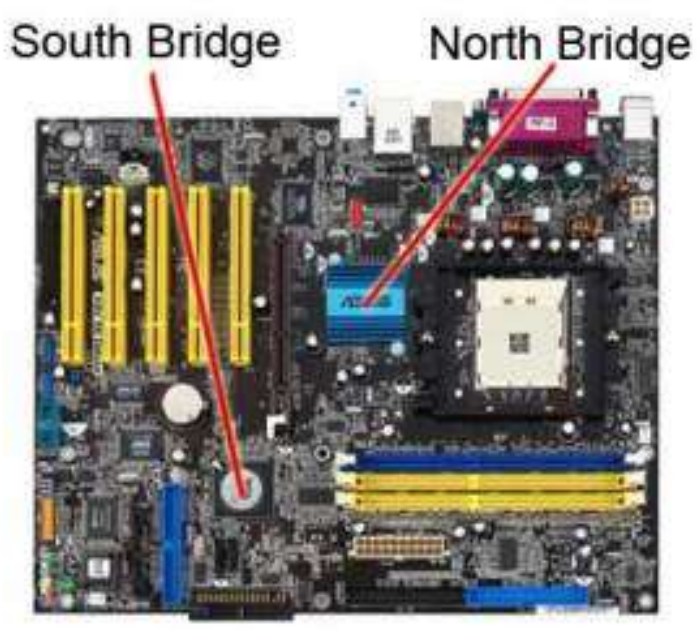

\section{Chipset southbridge}

yaitu chipset yang berfungsi untuk pengatur alur data kinerja prosessor dengan komponen sekunder seperti: IDE harddisk, drive, DMA dan lain-lain.

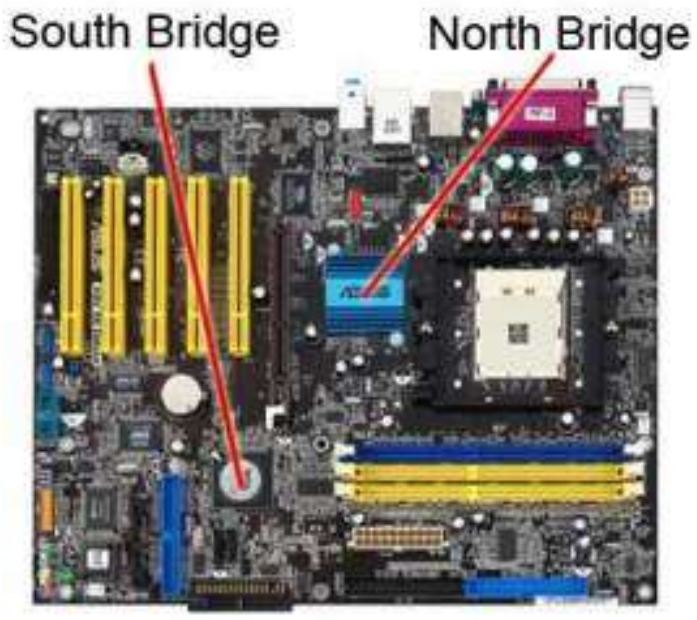

\section{Slot PCI Express X16}

Slot ini berfungsi untuk menancapkan kartu VGA dengan model terbaru.

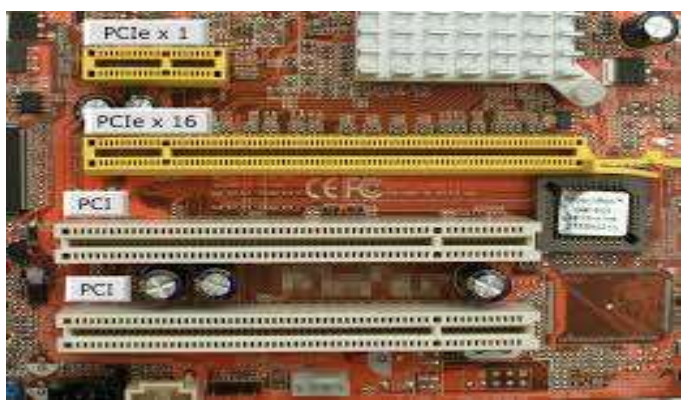

\section{Slot PCI Express x1}

Slot yang berwarna putih yang berbentuk memanjang yang berfungsi untuk menancapkan kartu ekspansi ke motherboard, kartu ekspansi meliputi LAN Card dan lain-lain.
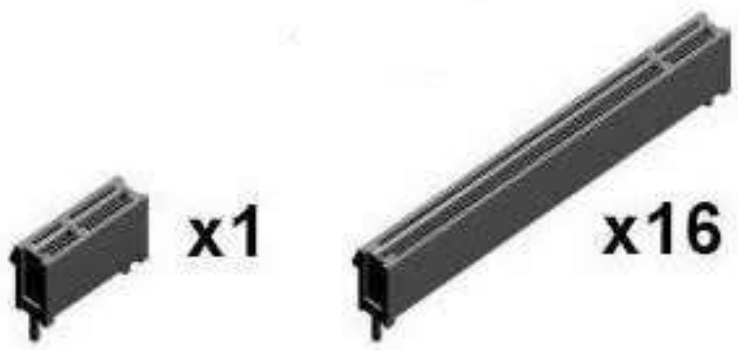

\section{Slot AGP}

Adalah slot pada komputer yang berfungsi untuk menancapkan kartu VGA ke motherboard, slot ini digunakan untuk motherboard yang belum mempunyai slot PCI Express x16.

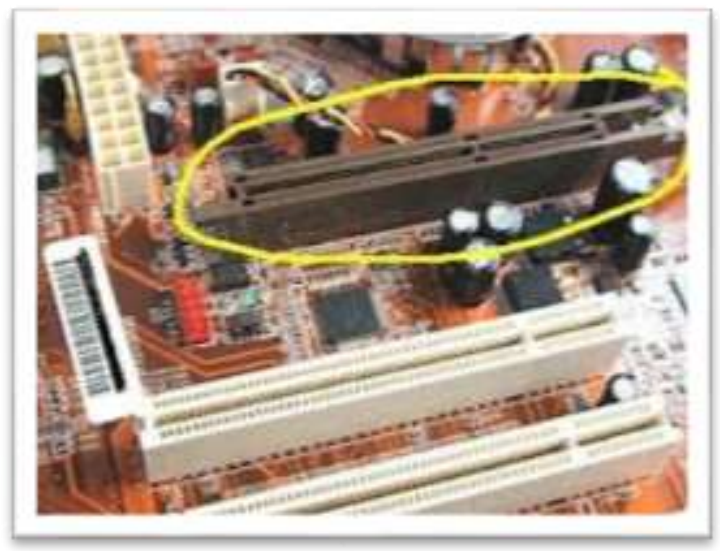

\section{Slot PCI}

Slot yang mempunyai fungsi yang sama dengan slot PCI Express 1x, akan tetapi slot ini mempunyai kecepatan akses dibawah slot PCI Express 1x 


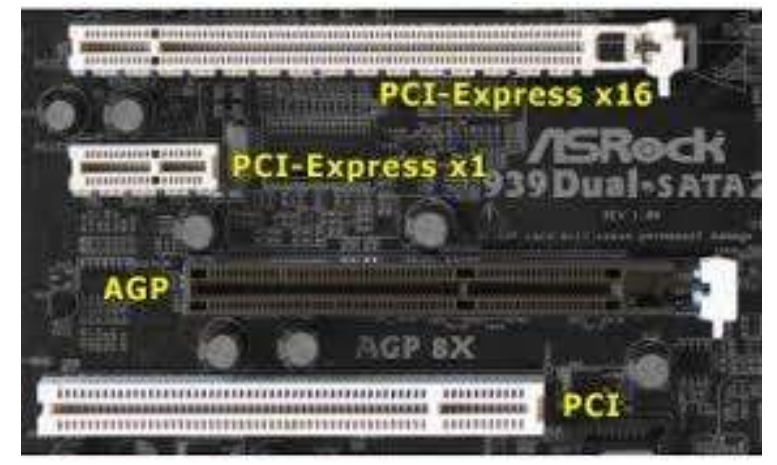

\section{Chipset BIOS}

Merupakan sebuah chipset yang menyimpan program bios dan konfigurasinya.

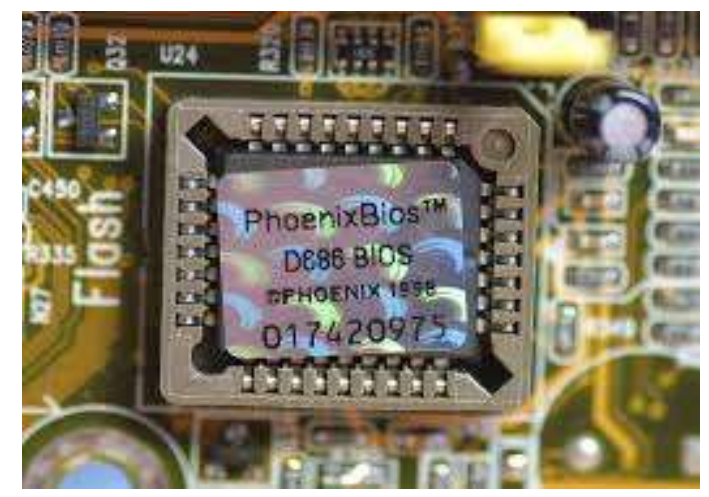

\section{Baterai CMOS}

Yaitu baterai khusus yang berfungsi untuk memeberikan daya ke chipset bios agar konfigurasi dari bios tidak kembali ke pengaturan awak ketika komputer dimatikan. Baterai ini berbentuk bulat.

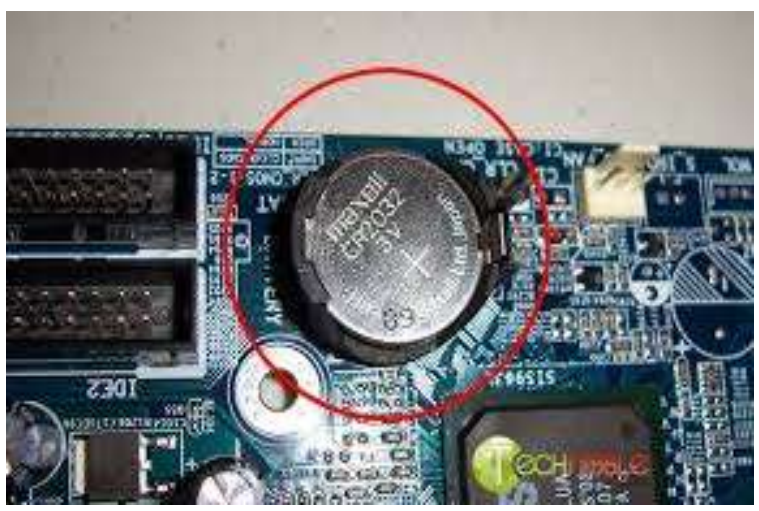

\section{Port SATA}

Port yang berfungsi untuk menghubungkan perangkat yang mempunyai port berbentuk SATA.

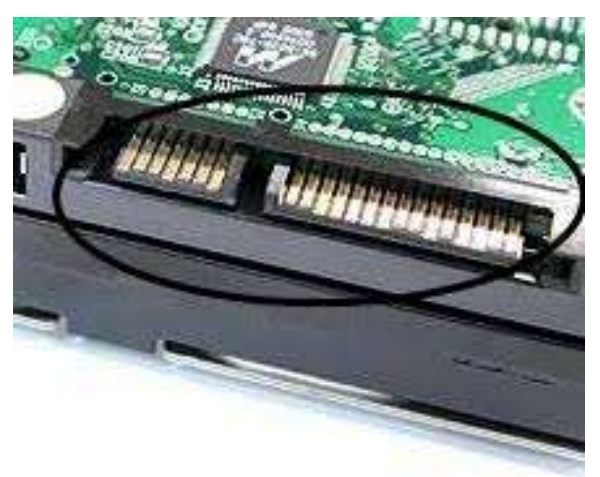

\section{Port IDE}

yaitu port yang berfungsi untuk menghubungkan perangkat yang mempunyai port ATA seperti CD Room model lama dan harddisk model lama.

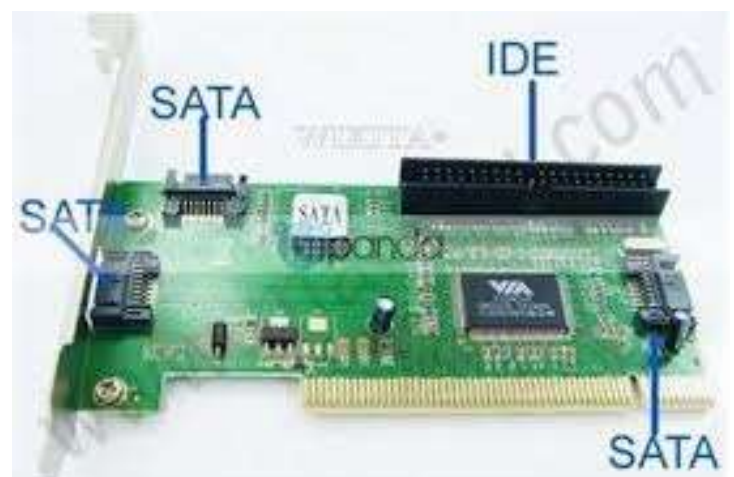

\section{Port Floppy Disk / Floppy Disk Drive}

Port yang berfungsi untuk menguhubungkan floppy disk dengan motherboard

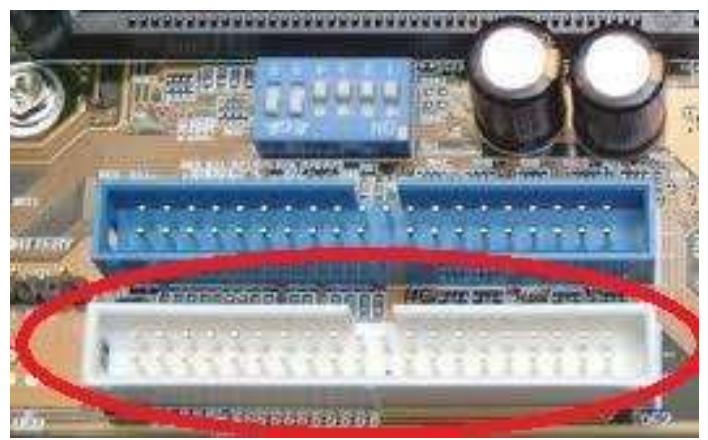




\section{Port PS/2}

yaitu port yang berada disisi samping motherboard yang berfungsi untuk menancapkan mouse dan keyboard. Port PS/ 2 ada 2 macam: ada yang berwarna ungu dan berwarna hijau yang mempunyai fungsi masing-masing. Port PS/2 yang berwarna ungu berfungsi untuk menancapkan keyboard dan port yang berwarna hijau berfungsi untuk menancapkan mouse.

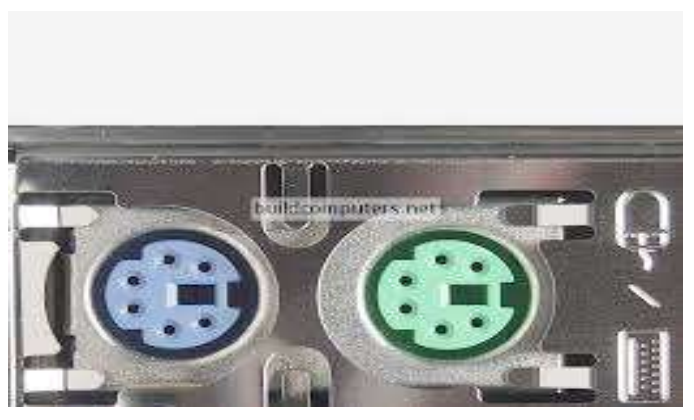

\section{Port Paralel}

Yaitu port yang berfungsi untuk memasang peripheral berkecepatan rendah dengan lebar data 8 bit. Akan tetapi port jenis ini sudah sangat jarang untuk digunakan.

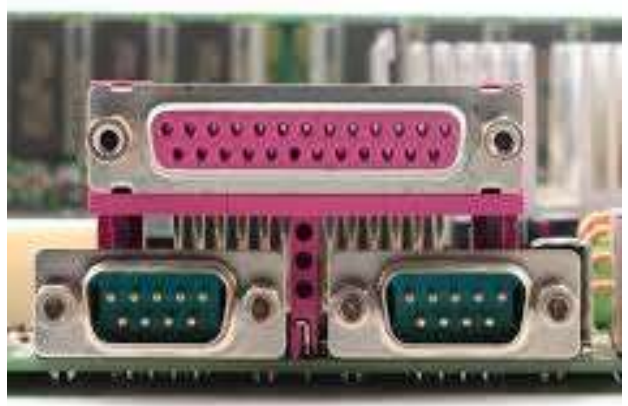

\section{wiseGEEK}

\section{Port RJ45}

Adalah port yang berfungsi untuk menghubungkan komputer ke jaringan.

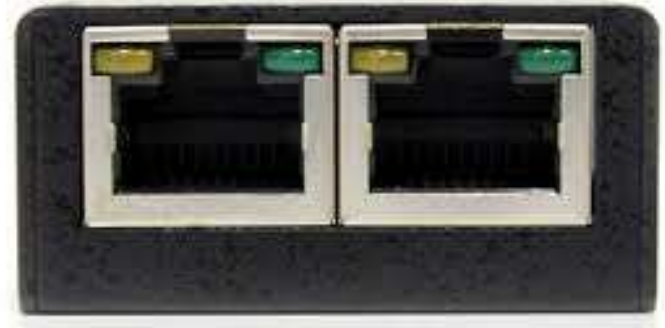

\section{Port USB}

Port yang berfungsi untuk menghubungkan perangkat atau peripheral yang mempunyai port USB seperti printer, kabel data, scanner dan lain-lain.

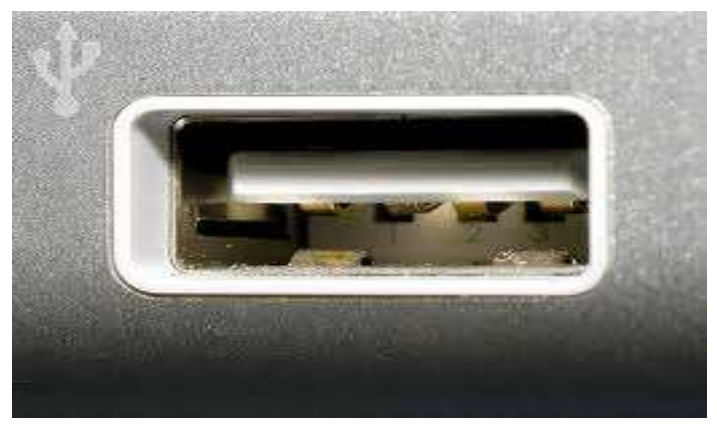

\section{Port Audio}

Yaitu port yang memiliki 3 port yang berfungsi untuk menghubungkan komputer ke perangkat audio. 3 port tersebut mempunyai fungsi yang berbeda-beda seperti: line-in, line-out dan mikrofon

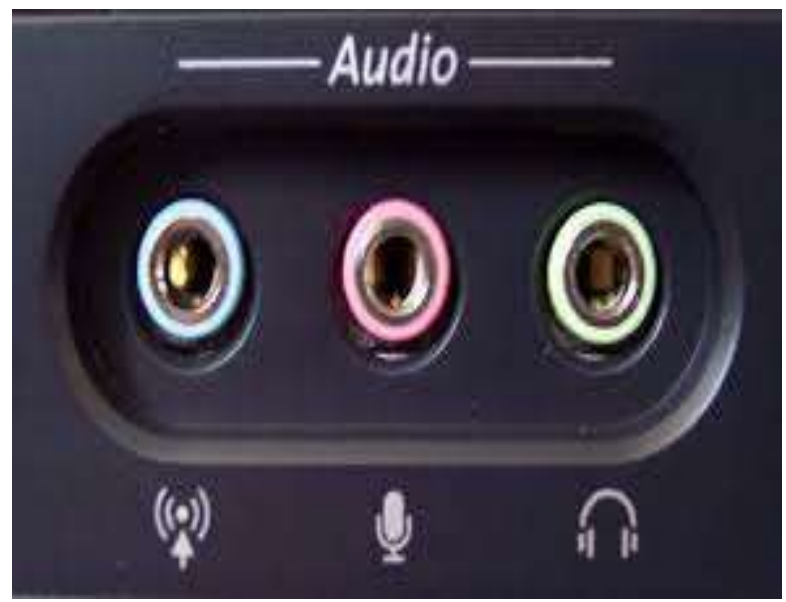


2.7 Pengertian VGA (Video Graphics Adapter)

VGA (Video Graphics Adapter)
adalah suatu perangkat keras
komputer yang berfungsi
menerjemahkan tampilan ke layar
monitor. VGA juga sering disebut
sebagai kartu grafis. VGA
digunakan untuk mengacu kepada
resolusi layar berukuran 640×480,
apa pun pembuat perangkat keras
kartu grafisnya. Untuk proses desain
grafis atau bermain permainan
video, diperlukan kartu grafis yang
berdaya tinggi. Selain itu, VGA juga
dapat mengacu kepada konektor
VGA 15-pin yang masih digunakan
secara luas untuk mengantarkan
sinyal video analog ke monitor.
Standar VGA secara resmi
digantikan oleh standar XGA, tetapi
nyatanya VGA justru digantikan
oleh Super VGA.

\subsection{Sejarah VGA (Video Graphics} Adapter)

Pada sebuah PC ada 3 komponen yang sangat penting dalam hal kinerja grafis, komponen tersebut yaitu : processor, momory dan VGA. VGA ( Video Graphics Adapter) merupakan standar tampilan komputer analog. VGA juga dapat diartikan sebagai komponen yang tugasnya menghasilkan visual dari komputer dan hardware yang emberikan perintah kepada komputer untuk menampilkan keluaran visual yang dapat kita lihat. VGA pertama kali dipasarkan pada tahun 1987 oleh International Bushiness Machines Corporation yang di singkat menjadi IBM. IBM adalah salah satu perusahaan AS yang memproduksi atau membuat perangkat keras dan perangkat lunak. IBM didirikan pada tanggal 15 Juli 1911 dan beroprasi pada tahun 1888 yang berpusat di Armonk, New York, dan AS.

\section{Perkembangan 3D Graphics}

Saat ini teknologi sudah semakin maju dan berkembang, para developer-developer GPU (Graphics Processing Unit) mulai meningkatkan kemampuan mereka dalam menghasilkan sebuah vga card yang bagus. Berikut ini adalah beberapa contoh vga card dari yang pertama hingga yang sekarang ini :

\section{S3 ViRGE}

Kepanjangan dari "ViRGE adalah Virtual Reality Graphics Engine”, vga ini merupakan generasi pertama yang telah menggunakan teknologi 3D grafik. S3 ViRGE memiliki spec. 
64-bit menawarkan 4 MB memory

onboard, core dan memory clockspeeds up to $66 \mathrm{MHz}$, dan juga telah mendukung fitur-fitur seperti Bilinear dan Trilenear texture filtering, MIP mapping, Alpha blending, Z-buffering, dan 3D tekstur lainnya.

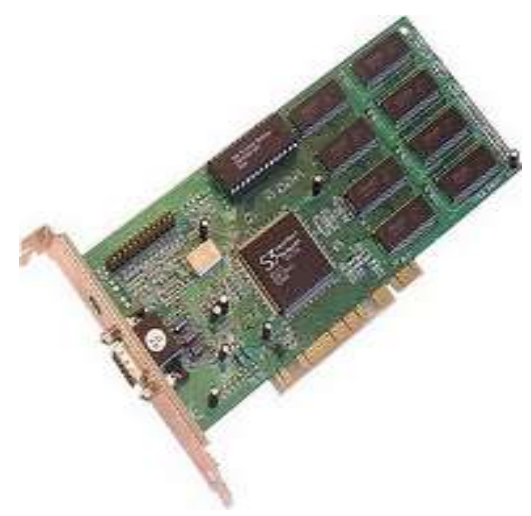

2. ATI RAGE $3 \mathrm{D} \&$ RAGE II

ATI RAGE II memiliki spec. 32-bit memory bus, dan memorynya hanya 2 MB. Karena kelemahan yang ada pada ATI RAGE 3D maka dibuatlah lagu seri ke-2nya yang diberi nama RAGE II yang memiliki spec. $8 \mathrm{MB}$ SDRAM, 64-bit memory bus, memory clockspeeds up to $60 \mathrm{MHz}$, serta mendukung kemampuan untuk memutar DVD Playback.

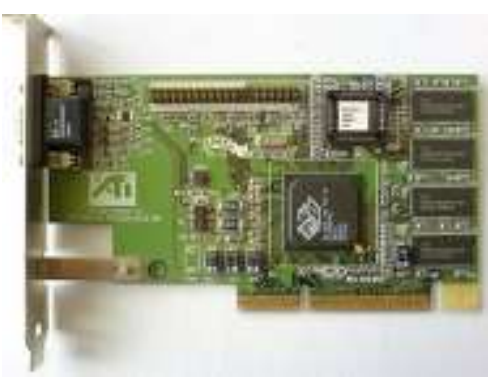

\section{NVIDIA NV3}

VGA ini adalah buatan pertama dari Nvidia, vga ini juga dibuat dengan desain teknologi Microsoft's DirectX 5 API. NVIDIA NV3 memiliki spec. 4 MB memory, 100 MHz core clockspeeds, bandwith 1.6 GB/s, $206 \mathrm{MHz}$ RAMDAC dan mendukung AGP 2x.

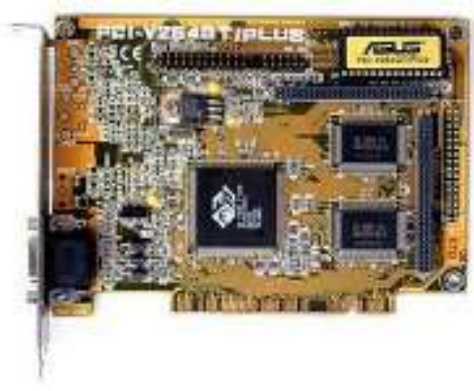

\section{NVIDIA NV4}

VGA ini merupaka penerus dari NVIDIA NV3, namun NVIDIA NV4 tidak ada penambahan yamh signifikan dalam spec. seperti memory maksimum ditambah menjadi $16 \mathrm{MB}$ dan mempunyai clockspeeds pada $110 \mathrm{MHz}$, tetapi Nvidia manambahkan beberapa kemampuan pada NVIDIA NV4 seperti teknologi "second pixel pipeline", 32-bit true colors, dan fitur Trilinear filtering.

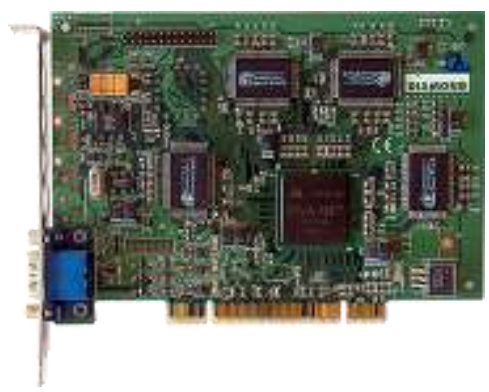




\section{NVIDIA GEFORCE 256}

VGA Nvidia ini memiliki kecepatan performa 2 kali lebih cepat daripada seri-seri sebelumnya, vga ini memiliki spec. DirectX 7, 4-pixel Rendering pipeline dan sebuah fitur bernama "cube environment mapping” yaitu yang gunanyauntuk menciptakan efek real time reflection.

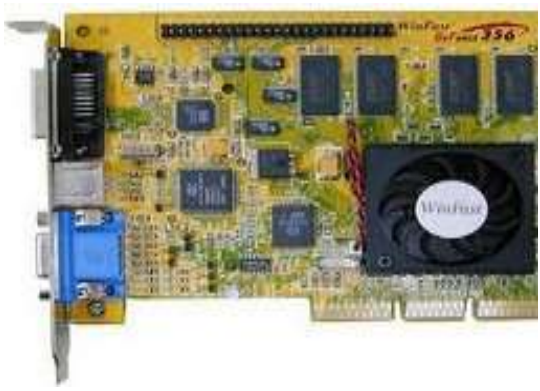

6. NVIDIA

GEFORCE SERIES 2

Ini merupakan vga Nvidia pertama yang menghadirkan fitur baru, yaitu pixel shader dengan sebutan "Nvidia Shading Rasterizer (NZR)”.

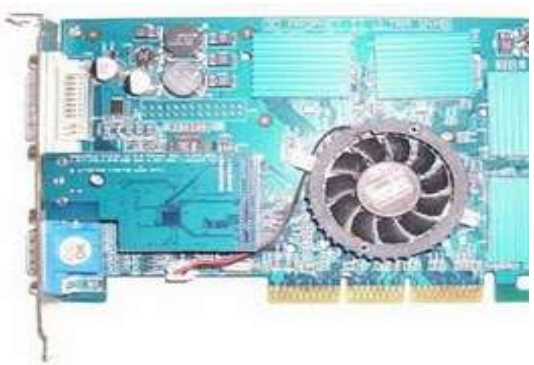

\section{ATI RADEON R520}

VGA ini menghadirkan spec. memory yang lebih efisien, kualitas image yang lebih baik dan performa yang optimal. Selain itu vga ini memiliki fitur seperti kemampuan High Dynamic Range (HDR) lighting.

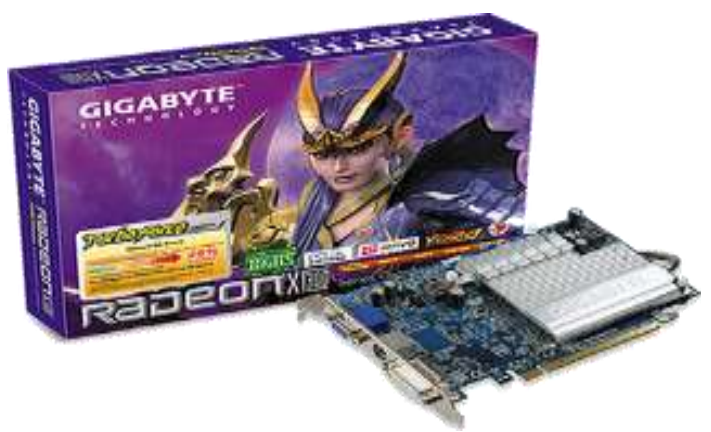

7. NVIDIA GEFORC SERIES

VGA ini merupakan keluaran dari Nvidia yang paling populer dikalangan masyarakat, karena termasuk vga "High End" dan yang paling terkenal yaitu NVDIA GEFORCE 9800 GTX yang memiliki 128 stream processor, dan 256-bit memory bus.

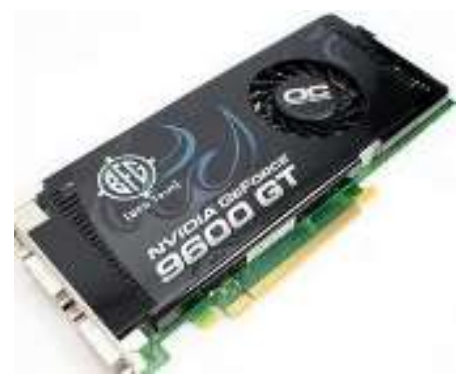

8. NVIDIA GEFORCE 200 SERIES

VGA ini memiliki chipset keluaran terbaru dari Nvidia berhasil memaukkan 1.4 billion transistor ke 
dalam GPU. VGA ini juga REFERENSI

merupakan seri Nvidia yang paling terkencang dan kemampuan yang powerful. (warga, 2012)

http://genggaminternet.com/macam-inputdevice-perangkat-masukan-komputer/

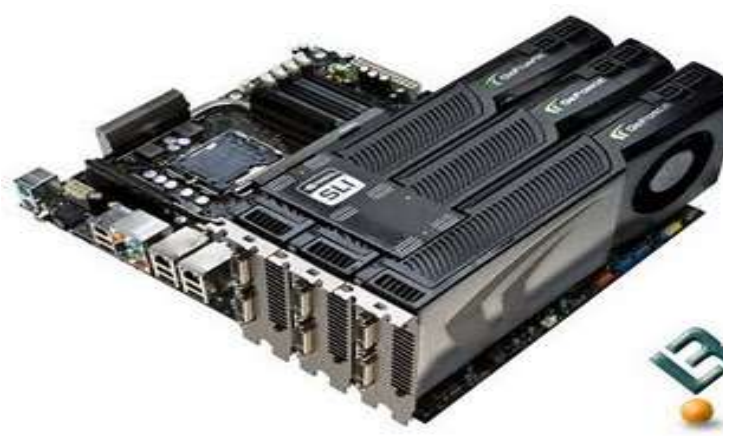

https://www.academia.edu/9333273/Makal ah_Hardware_Komputer

https://salamadian.com/perangkat-inputdan-output-komputer/

\section{KESIMPULAN}

Berdasarkan analisa yang telah dilakukan serta hasil yang telah diperoleh selama perancangan dan pembuatan aplikasi pengenalan hardware komputer ini, maka dapat ditarik kesimpulan bahwa aplikasi ini bisa menjadi sarana informasi untuk mempelajari hardware komputer yang memberikan pengetahuan lebih tentang nama dan fungsi dari masing - masing hardware yang ada pada komputer. Selain itu, aplikasi ini dibuat ke dalam bentuk yang interaktif dengan menampilkan beberapa menu pembagian hardware komputer berdasarkan fungsi dan contoh dari setiap hardware tersebut dengan desain tampilan yang menarik dan mudah digunakan oleh pengguna. 